\title{
TEN YEARS EXPERIENCE WITH A NEW STRATEGY OF PARTIAL DEAFNESS TREATMENT
}

\author{
Henryk Skarzynski ${ }^{1,2}$ \\ ${ }^{1}$ Institute of Physiology and Pathology of Hearing, ul. Zgrupowania AK "Kampinos" 1, 01-943 Warszawa, Poland \\ ${ }^{2}$ World Hearing Center, ul. Mokra 17, Kajetany 05-830 Nadarzyn, Poland
}

Corresponding author: Henryk Skarzynski, Institute of Physiology and Pathology of Hearing, ul. Zgrupowania AK "Kampinos" 1, 01-943 Warszawa, Poland

\begin{abstract}
What is now known as partial deafness treatment (PDT) began as a great challenge: insert a cochlear implant and preserve residual preoperative hearing. PDT addresses the situation where patients have low frequency hearing which is not badly affected, or is even fully functional, and it is necessary to complement it electrically in the medium and high frequency ranges. The first surgery in which existing normal hearing was electrically complemented, performed 10 years ago, has opened up a new direction in the treatment of other (more frequent) partial hearing impairments. The long term observation of more than 1200 ears has allowed us to refine a new strategy of PDT.

The first surgery to electrically complement the existing hearing of an adult was performed in 2002, and led in 2004 to the same treatment in a child. It was preceded with 3 years of research on how to enhance the low-frequency residual hearing of patients by amplifying it with conventional hearing aids while supplying high frequencies with an electrically stimulated implant. Results of these studies, presented in 2000 at international conferences, demonstrated the potential for widening the first, cautious indications for the use of cochlear implants to situations where there are various levels of residual low-frequency hearing. Experience with 1200 cases of partial deafness surgery have proven its general validity and have refined the surgical guidelines. The surgical strategy is based on 6 main steps involving an approach to scala tympani through the round window, and use of electrodes with an active length of 20 to $28 \mathrm{~mm}$.
\end{abstract}

Key words: partial deafness treatment $\bullet$ hearing preservation $\bullet$ electric and acoustic stimulation • cochlear implants $\bullet$ classification of deafness $\bullet$ round window approach $\bullet$ surgical technique

\section{DIEZ AÑOS DE EXPERIENCIA CON UNA NUEVA ESTRATEGIA DE TRATAMIENTO DE LA SORDERA PARCIAL}

\section{Resumen}

Lo que ahora se conoce como tratamiento de la sordera parcial (PDT) comenzó como un gran desafío: insertar un implante coclear y preservar la audición residual preoperatoria. El tratamiento PDT se aplica en las situaciones en las que los pacientes tienen una audición de baja frecuencia que no está muy afectada, o incluso es totalmente funcional, y es necesario complementarla eléctricamente en los rangos de frecuencia media y alta. La primera cirugía, realizada hace 10 años, en la que se complementó eléctricamente una audición normal existente, abrió una nueva dirección en el tratamiento de otros problemas (más frecuentes) de audición parcial. La observación a largo plazo de más de 1200 oídos nos ha permitido afinar una nueva estrategia de la PDT.

La primera cirugía para complementar eléctricamente la audición existente de un adulto se llevó a cabo en el año 2002, y condujo en 2004 al mismo tratamiento en un niño. Fue precedido con 3 años de investigación sobre cómo mejorar la audición residual de baja frecuencia de los pacientes mediante la amplificación con audífonos convencionales, mientras que se suministraba altas frecuencias con un implante estimulado eléctricamente. Los resultados de estos estudios, presentados en el año 2000 en conferencias internacionales, han demostrado el potencial para ampliar las primeras indicaciones cautelosas para el uso de implantes cocleares en situaciones donde hay varios niveles de audición residual de baja frecuencia. La experiencia con 1200 casos de cirugía de la sordera parcial ha demostrado su validez general y ha ayudado en perfeccionar las pautas quirúrgicas. La estrategia quirúrgica se basa en 6 pasos principales que implican un enfoque en la rampa timpánica a través de la ventana redonda, y el uso de electrodos con una longitud activa de 20 a $28 \mathrm{~mm}$.

Palabras clave: tratamiento de la sordera parcial • preservación de la audición • estimulación eléctrica y acústica • implantes cocleares • clasificación de la sordera • enfoque en la ventana redonda, técnica quirúrgica 


\section{ANS D’EXPÉRIENCE AVEC UNE NOUVELLE STRATÉGIE DE TRAITEMENT DE LA SURDITÉ PARTIELLE}

\section{Résumé}

Ce que nous savons aujourd'hui sur le traitement de la surdité partielle a débuté par un grand défi: insérer un implant cochléaire et préserver l'audition résiduelle préopératoire. Le traitement de la surdité partielle intevient envers les patients qui ont l'audition en basses fréquences pleinement ou partialement fonctionnelle, et chez lesquels il est nécessaire de compléter électriquement l'audition des moyennes et hautes fréquences. L'opération consistant à compléter électriquement l'audition naturelle normale a été réalisée pour la première fois il y a 10 ans. Cette opération a ouvert une nouvelle voie dans le traitement d'autres (plus fréquents) troubles de l'audition partielle. L'observation à long terme de plus de 1200 oreilles nous a permis d'affiner une nouvelle stratégie de traitement de la surdité partielle.

La première intervention chirurgicale où l'audition existante était électriquement complétée a été réalisée sur un adulte en 2002, et a conduitau même traitement chez un enfant en 2004. Précédemment, 3 années de recherche étaient nécessaires sur les moyens d'améliorer l'audition résiduelle en basses fréquences des patients avec les amplificateurs auditifs conventionnels, en fournissant de plus les hautes fréquences avec un implant stimulé électriquement. Les résultats de ces études, présentés en 2000 lors des conférences internationales, ont démontré la possibilité d’élargir les premières indications prudentes pour l'utilisation des implants cochléaires chez les patients avec différents niveaux d’audition résiduelle en basses fréquences. Les 1200 opérations de la surdité partielle ont prouvé leur efficacité et ont permis d'affiner les indicationspour l'intervention chirugicale. La stratégie de l’opération est basée sur 6 étapes principales nécessitant l'accès à la rampe tympanique par la fenêtre ronde, et l'utilisation des électrodes d'une longueur active de 20 à $28 \mathrm{~mm}$.

Mots-clés: traitement de la surdité partielle $\bullet$ préservation auditive $\bullet$ stimulation électrique et acoustique $\bullet$ implants cochléaires - classification de la surdité • accès par la fenêtre ronde • technique chirurgicale

\section{ДЕСЯТИЛЕТНИЙ ОПЫТ ПРИМЕНЕНИЯ НОВОЙ СТРАТЕГИИ ЛЕЧЕНИЯ ЧАСТИЧНОЙ ГЛУХОТЫ}

\section{Краткий обзор}

На сегодняшний день известно, что лечение частичной глухоты (PDT) изначально было сопряжено со значительными трудностями: установить кохлеарный имплантат и сохранить остаточную дооперационную остроту слуха. Лечение частичной глухоты относится к ситуации, при которой у пациентов сохраняется слышимость в диапазоне низких частот, без выраженных нарушений или даже с полным их отсутствием, при этом необходимо дополнить ее с помощью электрических сигналов в диапазоне средних и высоких частот. Первое хирургическое вмешательство, при котором нормальный слух был дополнен электрическими сигналами, было проведено 10 лет назад и открыло новые перспективы в лечении прочих (более часто встречающихся) частичных нарушений остроты слуха. Длительное наблюдение за слуховыми анализаторами в количестве более 1200 позволили нам выделить новую стратегию лечения частичной глухоты.

Первая операция по дополнению слуха электрическими сигналами у взрослого пациента была проведена в 2002 г., с последующим проведением в 2004 г аналогичной операции на ребенке. До проведения операции в течение 3 лет проводились исследования для повышения у пациентов остаточной остроты слуха в диапазоне низких частот с помощью традиционных усилительных устройств и обеспечения слышимости в диапазоне высоких частот с помощью имплантированного электрического стимулятора. Результаты таких исследований, представленные в 2000 г. на международных конференциях, показали возможность расширения первых, ограниченных показаний к применению кохлеарных имплантатов применительно к ситуациям, при которых сохраняется остаточная слышимость в диапазоне низких частот. Опыт, полученный в ходе оперативного лечения частичной глухоты у 1200 пациентов, показал общую приемлемость метода и позволил усовершенствовать руководства по проведению хирургических операций. Оперативная стратегия основана на 6 основных этапах, в том числе открытие доступа к барабанной лестнице через окно улитки и применение электродов с рабочей длиной от 20 до 20 мм.

Ключевые слова: лечение частичной глухоты • сохранение остроты слуха • электрическая и акустическая стимуляция • кохлеарные имплантаты • классификация видов глухоты • доступ к окну улитки • техника оперативного вмешательства 


\section{Background}

With steadily improving results for treating profound hearing loss and total deafness, notably in younger and younger children, researchers have been encouraged to progressively widen the indications for using cochlear implants. These studies have been conducted independently in Europe [1], in the USA [2], and in Australia [3]. They focus mostly on cases of electric stimulation with a cochlear implant in one ear and a hearing aid in the other, and less often with one-sided electric and acoustic stimulation.

In 2000, the first results on 67 children in which there was in the same ear - preserved residual hearing augmented by a hearing aid and electric stimulation by a cochlear implant, was presented by our team at the $5^{\text {th }}$ European Symposium on Paediatric Cochlear Implantation (ESPCI) Conference in Antwerp [4]. These results demonstrated the soundness of this approach and that there was potential for further development. In the same year, at the European Federation of Oto-Rhino-Laryngological Societies (EUFOS) Congress in Berlin, we presented the results of preservation of the residual hearing in the first group of adult patients [5].

Observations of the preservation of residual hearing, over $2-3$ years, showed that it was justified to widen the indications for using cochlear implants to include electric complementation of good (even normal) hearing at low frequencies (below $500 \mathrm{~Hz}$ ). Electric complementation was applied for the first time in an adult patient in 2002 [6], and in the first child in 2004 [7]. The surgical procedure was that proposed by Skarzynski as a 6-step strategy that includes an approach to scala tympani through the round window, a method of electrode insertion that physiologically offers the most direct path to the inner ear [8].

A growing number of patients, which soon reached several hundred and later fifteen hundred, demonstrated the validity of going in this direction. It has been confirmed by numerous articles and presentation of material at continental conferences and congresses on cochlear implants, audiology, and otology $[8,9]$. The reports have described new groups of patients, longer follow-up times, preservation of pre-operative hearing in ensuing years, as well as new technologies for cochlear implant electrodes [10,11]. In 2009, during the 9th ESPCI conference in Warsaw, we presented a new classification scheme based on different pre-operative levels of hearing at low frequencies [9]. In 2010, a more comprehensive scheme, which illustrates the differences in approaches to different groups of patients with partial deafness (see Figure 1), was presented [8].

All surgeries involving cochlear implantation (CI) were performed using the 6-step Skarzynski surgical technique which leaves inner ear structures intact [8]. Development of atraumatic surgical methods has allowed the indications for cochlear implantation to be extended to an increasing number of patients; it has also seen the emergence of new technologies and delicate CI electrode arrays of various lengths [10]. In a recent development, the 6-step Skarzynski surgical technique has been used in conjunction with limited electric stimulation of the cochlea using a 20-25 mm electrode array [11]. Most recently, deep insertion of $28 \mathrm{~mm}$ was performed while preserving residual hearing at $250 \mathrm{~Hz}$, which was subsequently effectively amplified by an electro-acoustic combination of hearing aid and cochlear implant [12].

The classification of partial deafness treatment (PDT) was first suggested by Skarzynski [8]. The model is important for evaluating the post-implantation performance in homogeneous groups of patients with various levels of preoperative residual hearing. Results obtained in distinct groups of patients by authors using various assessment methods can provide valuable data for further widening PDT selection criteria and helping to establish it as a common intervention. All these advancements have resulted in the development and more widespread use of

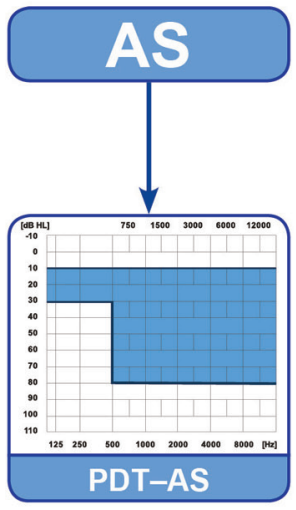

A

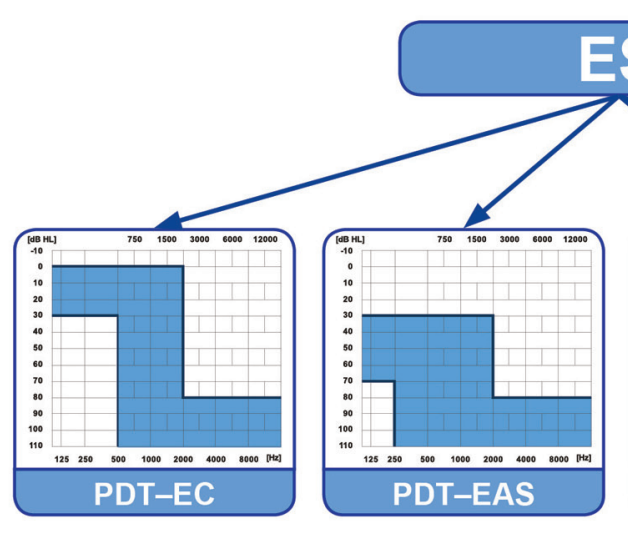

B
C

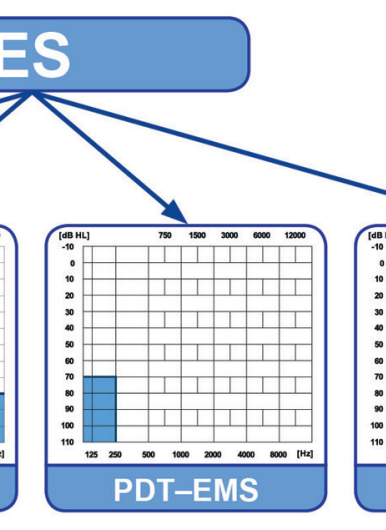

D

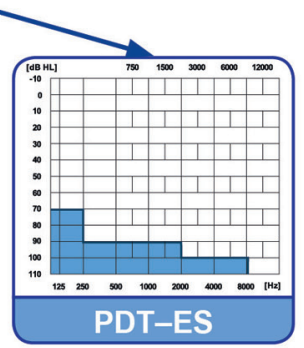

E

Figure 1. The latest classification scheme illustrates the different ways that acoustic stimulation (AS) and electric stimulation (ES) can be applied to treat partial deafness. (A) Amplification of acoustic hearing with hearing aids and middle ear implants (PDT-AS). (B) Electric complementation of existing good low-frequency hearing (PDT-EC). (C) Acoustic amplification with a hearing aid of residual hearing at low frequencies and electric stimulation of other parts of the same ear (PDT-EAS). (D) Modified electric stimulation in cases where pre-operative hearing has been lost without the possibility of re-operation (PDT-EMS). (E) Electric stimulation only in cases where residual hearing is non-functional over different frequencies (PDT-ES). 
Table 1. The 6-step Skarzynski surgical technique for cochlear implantation in partial deafness treatment.

\begin{tabular}{|c|c|}
\hline STEP 1 & Antromastoidotomy \\
\hline STEP 2 & Posterior tympanotomy to allow visualization of the round window niche \\
\hline STEP 3 & Puncture and incision of the round window membrane \\
\hline STEP 4 & $\begin{array}{l}\text { Approach to the scala tympani directly through the round window membrane (partial insertion of the } \\
\text { electrode array) }\end{array}$ \\
\hline STEP 5 & $\begin{array}{l}\text { Electrode fixation in the round window niche with fibrine glue (membrane must be partially uncovered } \\
\text { to preserve its mobility) }\end{array}$ \\
\hline STEP 6 & Fixation of the device in a well in the temporal bone \\
\hline
\end{tabular}

A

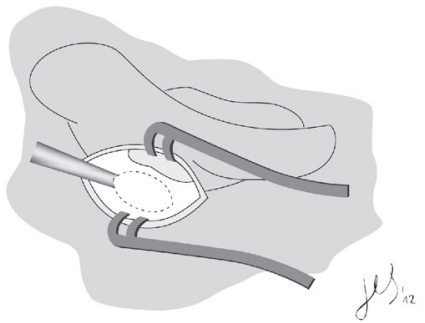

Figure 2. Delineation of a mastoid cortex plate (A), removal of the bony chip using a surgical chisel (B), closure of the mastoid cavity with the bony chip $(\mathbf{C})$.

new technologies in postoperative care such as telemedical networks and other health services. The appreciation of the benefits of PDT by patients and their families has speeded up investments in infrastructure, with the World Hearing Centre in Kajetany as an example.

\section{Material and Methods}

\section{Material}

During the last 10 years the PDT method has been used in 1512 patients (children and adults) aged from 9 months to 84 years. There have been 405 children and youths $\leq 18$ years old (26.8\%) and 1107 adults (73.2\%). Preoperative hearing thresholds were determined with audiometric tests in adults and children over 5 , and in younger children it was based on ABR at $0.5,1,2$, and $4 \mathrm{kHz}$. The most important group were the patients with normal or socially effective hearing up to $1500 \mathrm{~Hz}$ - PDT with electric complement (PDT-EC). As this group required only electric complementation of their existing hearing, they presented the largest challenge to the surgeon, but at the same time they were predisposed for achieving the best and fastest postoperative rehabilitation. The second group - PDT with combined electric and acoustic stimulation (PDT-EAS) has been until now the most numerous. This is probably due to the fact that these patients are the most determined to undergo cochlear implantation. The third group - PDT with modified electric stimulation (PDT-EMS) - was the least numerous and included only 3 children and 26 adults, amounting to $2.6 \%$ of the whole study group of 1512 ears.

In the 36 adults whose hearing deteriorated significantly during the 6 months after surgery, 27 of them (1.8\% of the whole study group) had bilateral deterioration of hearing (that is, not just in the operated ear) and $9(0.6 \%)$ had unilateral deterioration (in the operated ear, probably associated with surgery). Among children, significant deterioration of hearing was observed in only 3 patients, which constitutes $0.2 \%$ of the entire study group and $0.7 \%$ of the children, and deterioration was observed within 3 months of surgery only in the implanted ear. Six years after surgery, a level of preservation of pre-operative hearing was seen in $100 \%$ of children.

\section{Methods}

All surgical procedures presented in this paper involve the round window approach to scala tympani. In 1507 ears (99.7\%) the round window niche was accessed via posterior tympanotomy, with $5(0.3 \%)$ instances of combined access via posterior tympanotomy and the external auditory meatus. The additional procedure was necessary for good exposure of the round window niche and the electrode array was inserted via the previously drilled posterior tympanotomy. In all ears the electrodes were gently introduced into scala tympani via an incision in the round window membrane until an appropriate insertion depth was obtained. The whole intervention was performed according to the 6-step Skarzynski surgical technique (Table 1).

The first step of the procedure is conservative antromastoidectomy with wide enough drilling to insert the electrode array into the mastoid cavity. Prior to that step, especially in children, a chip of the mastoid cortex is removed using a surgical chisel. The specimen is later used to separate the mastoid cavity from the subcutaneous area where the internal part of the implant sits (Figure 2).

In the second step of the procedure, a posterior tympanotomy is performed (Figure 3 ). The access should be broad 


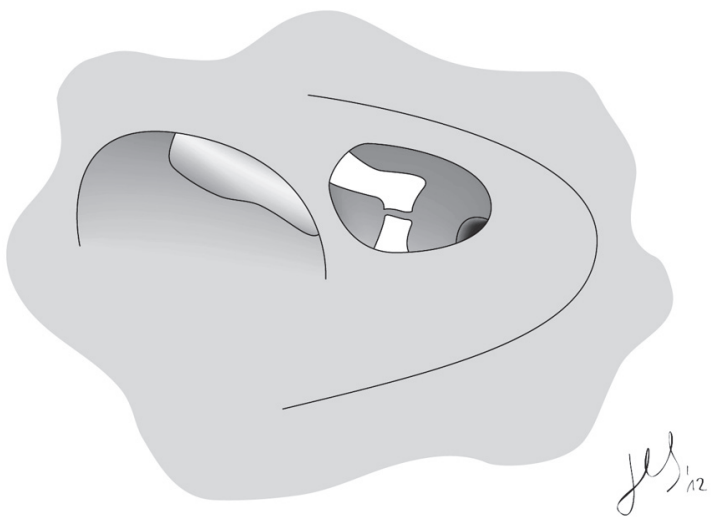

Figure 3. Posterior tympanotomy with exposure of the round window.

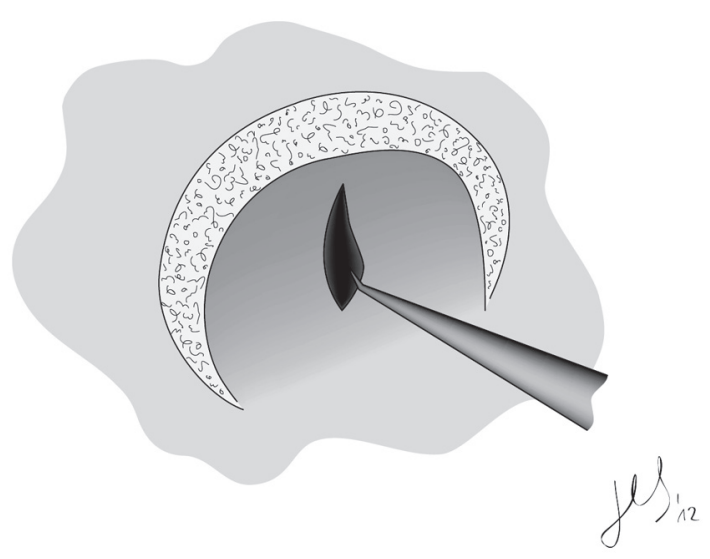

Figure 4. Third step of the Skarzynski surgical technique for cochlear implantation in partial deafness treatment: puncture and incision of the round window membrane.

enough for the surgeon to be able to visually follow the electrode insertion into the round window niche. For better exposure of the round window membrane, in some cases the bony lip has to be removed and in some ears combined access via the external auditory meatus is necessary.

The third step of the procedure involves careful puncture and incision of the round window membrane for insertion of the electrode array into scala tympani (Figure 4).

The crucial fourth step of the procedure involves electrode insertion at an angle almost perpendicular to the surface of the round window membrane (Figure 5). The author recommends this position of the array prior to its introduction into scala tympani as the least traumatic. Preferably, at the initial stages, the array should be inserted with fingers to allow better estimation of the cochlear resistance. Only at the final stages can forceps be used.

The fifth step of the procedure involves sealing of the insertion site and fixing the array in the posterior tympanotomy using fascia and a tissue adhesive (Figure 6). The remaining part of the array is bundled in the mastoid cavity.

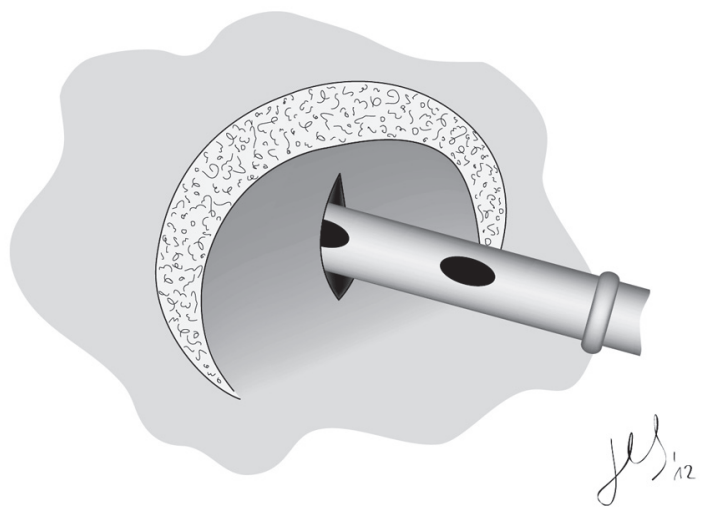

Figure 5. Fourth step of the Skarzynski surgical technique: insertion of electrodes into scala tympani.

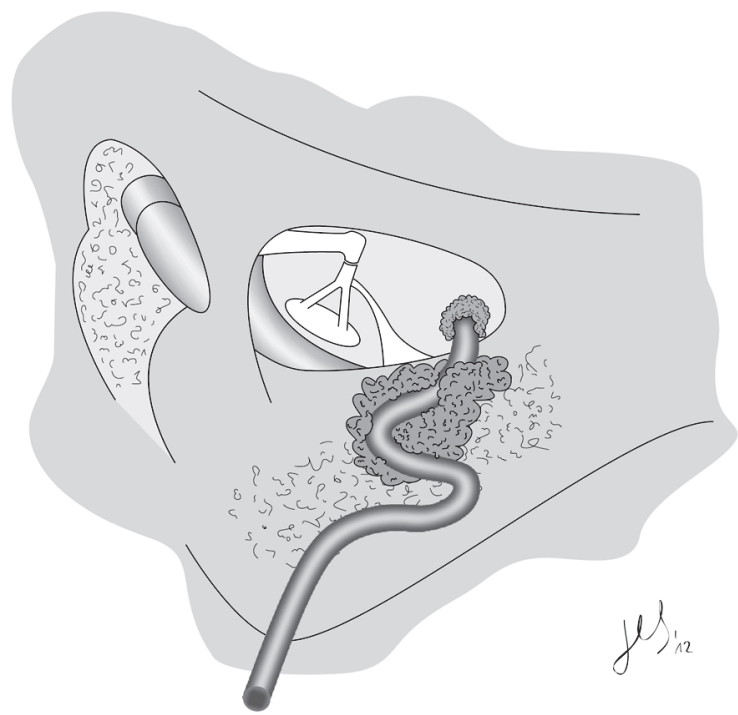

Figure 6. Fifth step: sealing and fixing the electrode array.

The access to the mastoid is sealed with Spongostan ${ }^{\circ}$ and the mastoid chip collected in the first step of the procedure.

In the final sixth step, a well for the internal part of the implant is drilled in the temporal bone and the element is fixed using glass-ionomer cement and non-absorbable sutures (Figure 2C). Finally, the postauricular incision is sutured. In all adult patients and most of the children a suction drain is used for 2 days post-operatively.

Two cochlear implant systems were used in the study:

a. A Med-El ${ }^{\circledR}$ system with standard electrodes which were only partially inserted into the scala tympani (insertion depth 18-28 mm), shorter $20 \mathrm{~mm}$ Medium and Flex electrodes, and SoftFlex electrodes (insertion depth 22$28 \mathrm{~mm}$ ). Insertion deeper than $25 \mathrm{~mm}$ is termed "deep insertion" [12].

b. Cochlear ${ }^{\circledast}$ system: CI422/SRA $20 \mathrm{~mm}$ electrodes that can potentially be inserted deeper $(25 \mathrm{~mm})$ [11]

In case of partial deafness treatment with an electrical complement (PDT-EC), only speech processors were used. 


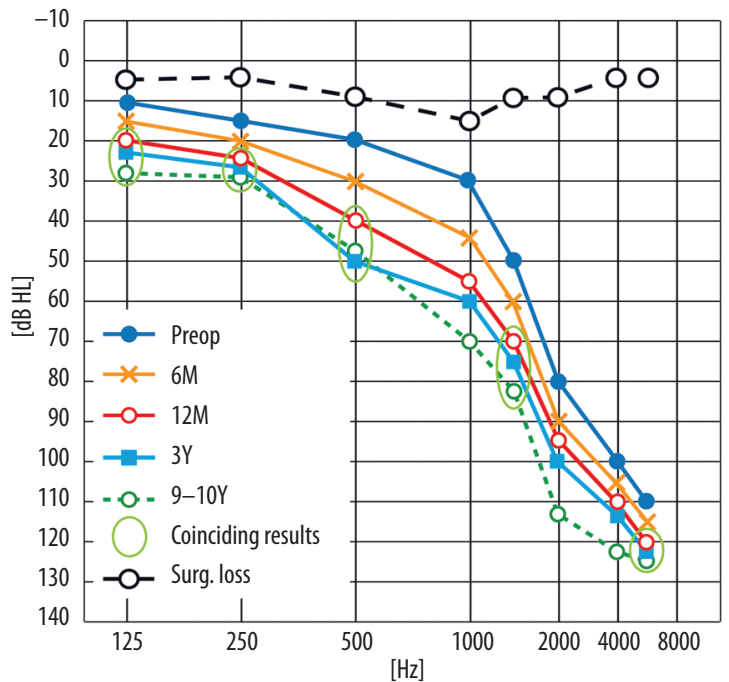

Figure 7. Preoperative thresholds and postoperative results of hearing preservation in the PDT-EC group collected over almost 10 years $(n=31)$.

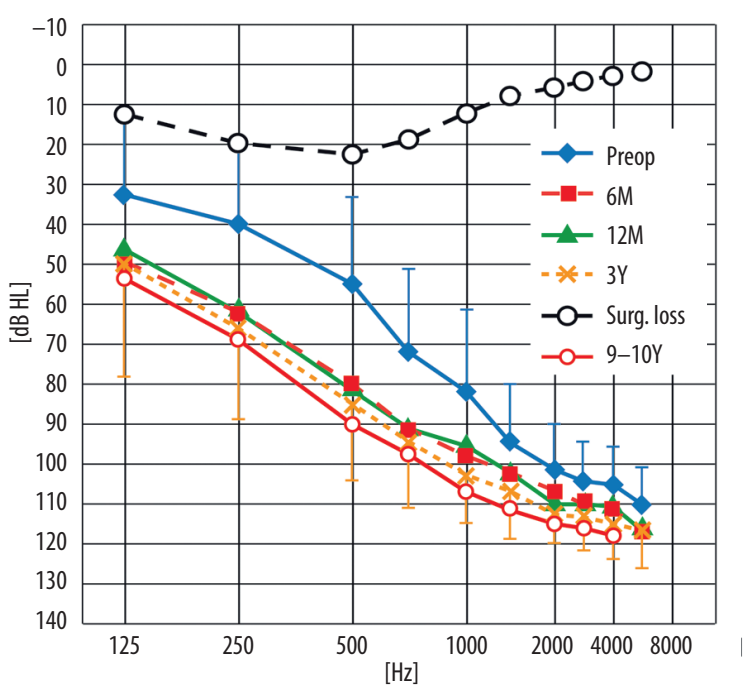

Figure 8. Pre- and post-operative thresholds in the PDTEAS group over almost 10 years $(n=43)$.

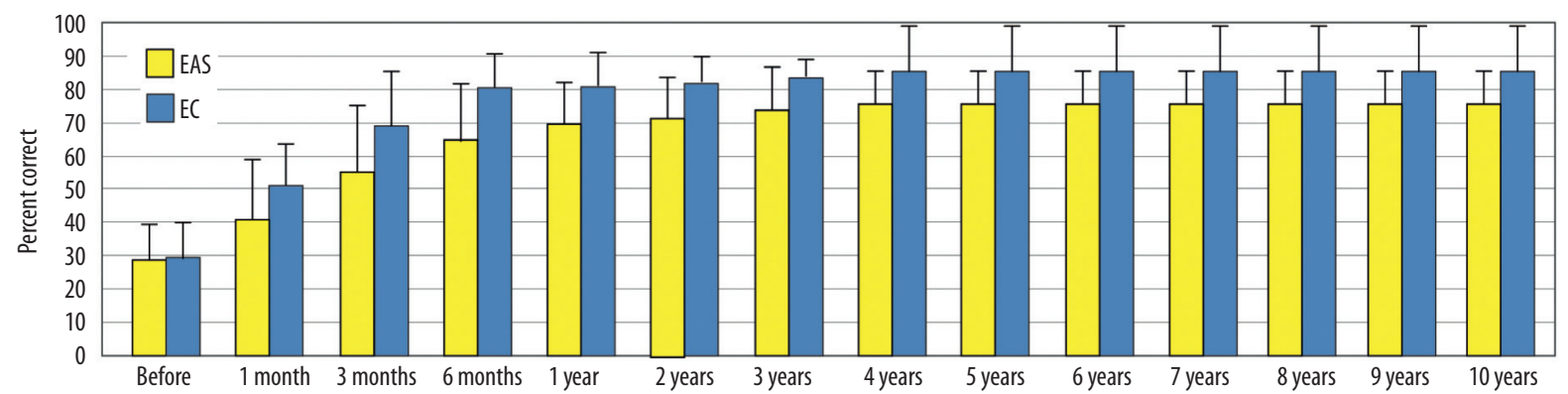

Figure 9. Speech recognition in quiet using the monosyllabic word test. PDT-EC (blue) and PDT-EAS (yellow).

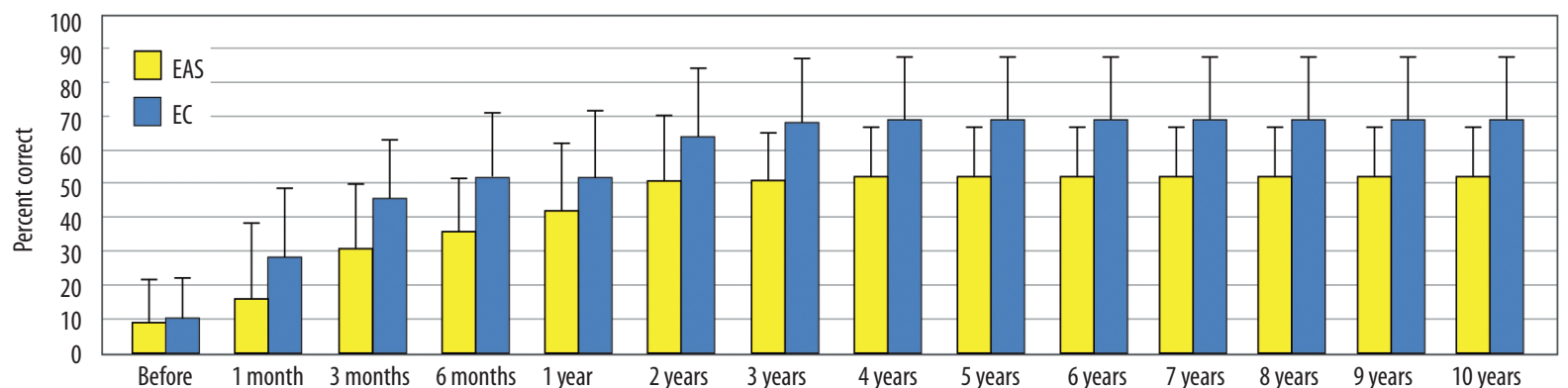

Figure 10. Speech recognition in noise using the monosyllabic word test. Key as for Figure 9.

In patients referred for electric and acoustic stimulation (PDT-EAS), first only hearing aids are recommended, followed by an EAS combination using a Duet or Hybrid system. Post-operative care, fitting, and PDT rehabilitation methods have been described elsewhere $[7,13]$.

\section{Results}

The new method, which enables acoustic and electric stimulation of the inner ear using cochlear implants of different electrode lengths, has broadened the indications for surgical treatment of hearing impaired patients. The most important and difficult task achieved in 2002 included implementation of PDT-EC: electric complementation of low frequencies and preservation of normal hearing at other frequencies [6]. Figure 7 presents averaged preoperative hearing thresholds and their long-term preservation (up to 10 years) in the group of 31 patients. 
Figure 7 shows the long-term preservation of preoperative hearing, especially in the range of low frequencies but also in the residual hearing at higher frequencies. The biggest threshold drop occurs at $1000 \mathrm{~Hz}$. Early postoperative assessment (first 2 months) indicated deterioration of about $10-15 \mathrm{~dB}$ at all frequencies. Threshold shifts within the next 3 to 6 months were not large. Therefore the thresholds obtained at 6 months were considered the starting point for the long-term observations ( 10 years). In the period from 12 months to 10 years post-op (considering the group of 31 patients), no major deterioration of hearing level at low frequencies in the first operated EC group was observed. (It should be emphasized that for the first 2 years of the treatment program, only adult patients with hearing remaining preoperatively stable over 10 years were selected for PDT-EC treatment; therefore preoperative hearing in the first group has been verified over a considerable period.)

Figure 8 depicts corresponding results in the first group of 43 patients with combined electric and acoustic stimulation - PDT-EAS over a 10 year period.

Hearing deteriorated by about $10-25 \mathrm{~dB}$ in the important low frequency range within the first 6 months, but was stable at frequencies above $1 \mathrm{kHz}$. In the following 9-year follow up period no major deterioration of hearing was observed. Important differences concerning permanent deterioration of hearing within the first months postoperatively and its occasional occurrence in the following years are not easy to explain. This situation can be at least partially explained by the fact that in the second, non-operated ear about $32.5 \%$ of patients showed deterioration of hearing. In addition, observations show that in $53.4 \%$ of cases hearing had been slightly deteriorating in both ears some years prior to the CI operation.

Therefore, it can be assumed that in those ears hearing was gradually deteriorating before and after the operation. Explanation of this condition will probably be possible after further collection and assessment of long term data collected in a bigger group of operated patients, which will be the topic of a separate multifaceted analysis.
In assessing the outcomes, a crucial aspect is speech perception performance. Figures 9 and 10 present results of speech perception. It is significant that over long periods of time, during which there was regular rehabilitation, the results were stable. Speech perception both in noise and quiet is higher in the PDT-EC group than in the PDT-EAS group.

In summary, a comprehensive concept of PDT on patients with different types of preoperative hearing has been presented, building on the findings of authors who have developed this method over a number of years $[8,10,11,14,15]$. This paper summarises the outcomes of PDT conducted from 2002 to 2012 on 74 patients. It confirms the usefulness of the classification scheme and the reliability of the surgical strategy. This work complements that reported by other teams on the surgical technique and PDT using similar patient selection criteria $[14,16,17]$.

\section{Conclusions}

1. Long term observations of a growing number of patients of different ages indicate the benefits of extending the inclusion criteria for cochlear implants in patients with significant residual hearing and normal preoperative hearing at low frequencies.

2. Stability of the results and good preservation of hearing have confirmed that the optimal surgical strategy is to apply the round window approach.

3. Results of clinical observations have accelerated the development of new cochlear implant electrodes. This is important not only for hearing preservation but also for preserving the preoperative structure of the inner ear.

4. This paper shows the high importance of preserving hearing. Associated developments include:

a. New detection strategies for various hearing disorders based on screening.

b. New directions in infrastructure and health teleinformation technologies.

\section{References:}

1. von Ilberg C, Kiefer J, Tillein J et al: Electric-acoustic stimulation of the auditory system. New technology for severe hearing loss. ORL J Otorhinolaryngol Relat Spec, 1999; 61: 334-40

2. Gantz BJ, Turner C, Gfeller K: Expanding cochlear implant technology: Combined electrical and acoustical speech processing. Cochlear Implants Int, 2004; 5(Suppl.1): 8-14

3. Briggs RJ, Tykocinski M, Stidham K, Roberson JB: Cochleostomy site: implications for electrode placement and hearing preservation. Acta Otolaryngol, 2005; 125: 870-76

4. Skarzynski H, Lorens A, Piotrowska A: Residual acoustic hearing in the ear before and after cochlear implantation. Presentation at the $5^{\text {th }}$ ESPCI in Antwerp, 2000

5. Skarzynski H, Lorens A, D'Haese P et al: Preservation of residual hearing in children and post-lingually deafened adults after cochlear implantation: an initial study. ORL J Otorhinolaryngol Relat Spec, 2002; 64: 247-53

6. Skarzynski H, Lorens A, Piotrowska A: A new method of partial deafness treatment. Med Sci Monit, 2003; 9(4): CS20-24
7. Skarzynski H, Lorens A, Piotrowska A, Anderson I: Partial deafness cochlear implantation in children. Int J Pediatr Otorhinolaryngol, 2007; 71: 1407-13

8. Skarzynski H, Lorens A, Piotrowska A, Skarzynski PH: Hearing preservation in partial deafness treatment. Med Sci Monit, 2010; 16(11): CR555-62

9. Skarzynski H, Lorens A: Partial deafness treatment. Cochlear Implants Int, 2010; 11(Suppl.1): 29-41

10. Skarzynski H, Podskarbi-Fayette R: A new cochlear implant electrode design for preservation of residual hearing: a temporal bone study. Acta Otolaryngol, 2010; 130: 435-42

11. Skarzynski H, Lorens A, Matusiak M et al: Partial deafness treatment with the Nucleus Straight Research Array Cochlear Implant. Audiol Neurootol, 2012; 17: 82-91

12. Skarzynski H, Lorens A, Zgoda $\mathrm{M}$ et al: Atraumatic round window deep insertion of cochlear electrodes. Acta Otolaryngol, 2011; 131: 740-49 
13. Skarzynski H, Lorens A, Piotrowska A, Anderson I: Partial deafness cochlear implantation provides benefit to a new population of individuals with hearing loss. Acta Otolaryngol, 2006; 126: $934-40$

14. Prentiss S, Sykes K, Staecker H: Partial deafness cochlear implantation at the University of Kansas: techniques and outcomes. J Am Acad Audiol, 2010; 21: 197-203
15. Lorens A, Zgoda M, Obrycka A, Skarzynski H: Fine Structure Processing improves speech perception as well as objective and subjective benefits in pediatric MED-EL COMBI 40+ users. Int J Pediatr Otorhinolaryngol, 2010; 74: 1372-78

16. Dorman MF, Gifford RH: Combining acoustic and electric stimulation in the service of speech recognition. Int J Audiol, 2010; 49: 912-19

17. Helbig S, Baumann U, Hey C, Helbig M: Hearing preservation after complete cochlear coverage in cochlear implantation with the free-fitting FLEXSOFT electrode carrier. Otol Neurotol, 2011; 32: 973-79 